Dr NIKOLA ŽUTIĆ, naučni savetnik

Institut za savremenu istoriju

Beograd, Trg Nikole Pašića 11

UDK 341.312(439)"1914/1918"(093.2)

316.644:94(100)"1914/1918"(410)"1919/1929"(093.2)

327(410:439)"1919/1929"(093.2)

\title{
MAĐARI O ODGOVORNOSTI ZA VELIKI RAT 1919-1929*
}

APSTRAKT: U članku se rekonstruiše i analizira odnos Britanije prema Mađarskoj, Njemačkoj i Austriji, kao i napisi u štampi o aktivnosti pojedinaca iz revizionističkih poraženih zemalja, koji su kritički pisali o sarajevskom događaju i uzrocima izbijanja Velikog rata.

Ključne reči: Veliki rat, Mađarska, Austro-Ugarska, Njemačka, Velika Britanija, Kraljevina SHS, Versajski mir, reparacije

\section{ODNOS BRITANIJE PREMA MAĐARSKOJ I AUSTRIJI U VERSAJSKOJ EVROPI}

Dio britanskog javnog mnjenja ublažavao je isključivu njemačkoaustrougarsku krivicu za rat, utvrđenu odredbama Versajskog mirovnog ugovora. Naime, Britanija se, između ostalog, iz privrednih i finansijskih razloga nastojala približiti poraženim državama srednje Evrope, jer je očekivala nastupajući ekonomski progres u zemljama Mitel Europe. Ekonomski kolaps Austrije Britanija je počela sanirati povoljnim kreditom od 2 miliona funti. Pošto je za London Beč bio finansijski centar centralne Evrope, njegov pad bi, prema mišljenju Engleza, predstavljao „izvor neizmjerne nesreće". Oni su se okretali ka konjukturnim interesima približavanja poraženim zemljama, pa su se samim time udaljavali od Francuske i zemalja Male Antante (Srbije, Poljske, Rumunije, pa čak i od Čehoslovačke).

Ubrzo poslije okončanja Velikog rata krojila se nova geopolitička mapa Evrope, koja je u novim savezništvima dobijala neočekivane zaplete. S druge strane, tokom 1923. počelo je okupljanje revizionista na čelu sa

Rad je deo projekta Srpsko društvo u jugoslovenskoj državi u 20. veku: između demokratije i diktature (177016), koji finansira Ministarstvo prosvete, nauke i tehnološkog razvoja Republike Srbije. 
nezadovoljnim pobjednikom Italijom. U julu 1923. italijanska vlada otpočela je razgovore u Beču o tajnom sporazumu sa Austrijom, po kome bi italijanska vlada u raznim pitanjima ukazivala pomoć Austriji, naročito u pogledu ekonomskog podizanja Austrije, a ova bi se sa svoje strane obavezala da stupi u „novu“ Malu Antantu. U svemu je izgleda imao udjela i Vatikan sa Rimokatoličkom crkvom. Ovi razgovori u Beču i velika aktivnost koju je italijanska diplomatija razvila u Sofiji i Budimpešti bili su pripremni radovi za novu Malu Antantu: Austrija - Ugarska - Bugarska. Osim toga, cilj ovih razgovora bio je da se parira tendenciji izvjesnih političkih krugova u Francuskoj koji su željeli Austriju uvući u tek formiranu Malu Antantu, što je jugoslavenskom poslaniku u Rimu V. Antonijeviću bilo poznato iz izjave koju mu je $u$ to vreme dao tamošnji francuski ambasador Baror. On je više puta svojoj vladi sugerisao da se Austrija uvuče u Malu Antantu. Za poslanika Antonijevića u cijeloj ovoj stvari bili su najvažniji i najozbiljniji "napori italijanske vlade da za ovakvu politiku pridobiju i englesku vladu“.

Prema izvještaju Glavnog generalštaba Kraljevine SHS, uhvaćen je mađarski špijun koji je izjavio da se iz Italije prevlači oružje preko Austrije za Mađarsku. Isti je izjavio da će se u oktobru u Mađarskoj proglasiti za kralja Oto, sin bivšeg cara Karla Habzburškog i da će sve bivše pokrajine carstva - Češka, Rumunija, Kraljevina SHS, biti prisajedinjene Mađarskoj. ${ }^{2}$

Države srednje i istočne Evrope, kako pobjedničke tako i gubitničke, činile su velike propagandne napore u Engleskoj kako bi zadobile simpatije uticajnog britanskog javnog mnjenja. Od novonastalih država najviše uspjeha kod Engleza imala je Čehoslovačka, zahvaljujući ogromnim sredstvima izdvojenim za propagandu, za koju se lično interesovao i sam liberalni predsjednik Tomaš Masarik. Od poraženih država na propagandi su najenergičnije i najnametljivije djelovali Mađari. Oni su i tokom 19. vijeka imali jakih veza u Engleskoj, naročito njihovo plemstvo, visoka buržoazija i jevrejski finansijski krugovi u Pešti. Poslije rata Mađari su radili prema novonastaloj situaciji, nastojeći da te veze „demokratizuju“, pa su tražili podršku u univerzitetskim centrima među profesorima i studentima. Centar ove akcije bio je u Oksfordu u kome je osnovano udruženje pod imenom „Oksfordska liga za mađarsko samoopredjeljenje“, koje je izdavalo časopis Oksfordsko- Ugarski pregled. ${ }^{3}$

${ }^{1}$ AJ, fond br. 341, f. 1923/f. 2, Poslanstvo Kraljevine Srba, Hrvata i Slovenaca u Rimu - ministru Ninčiću u Beograd, 2. avgust 1923.

${ }^{2}$ AJ, fond br. 341, f. 1923/f. 2, Ministarstvo inostranih dela Kraljevine SHS (dalje MID) - Kraljevskom poslanstvu u London, 19. oktobar 1923.

${ }^{3}$ Poslanik u Londonu je doznao da izdavač Bezil Blekuel ne nosi ni najmanju odgovornost za tu publikaciju, pošto je on samo agent koji prima plaću. Za prvi broj časopisa priloge su dala dva-tri Engleza; drugi broj nije sadržavao nijedan prilog engleskih autora već 
Istupajući sa radikalnih revizionističkih pozicija, Oksfordska liga je upozoravala na vrlo ozbiljnu situaciju koju je u centralnoj Evropi stvorio Trijanonski ugovor. Pri tome je navodila iskonstruisane argumente $u$ korist „svoje ispravne borbe za mađarska historijska nacionalna prava“: „Predratna Mađarska bila je određena granicama koje su stare hiljadu godina; ona je učinila neprocjenjive usluge svojom hrabrom odbranom zapadne civilizacije od Turske navale; Mađari su hrabar, lojalan i veoma kulturan narod; oni imaju duboko ukorijenjenu ljubav za Englesku, a ta ljubav je nadživila rat". U Ligi su smatrali da iako Mađarska nikad nije željela rat, s njom se vrlo loše postupalo po ugovoru o miru, jer je izgubila dvije trećine svoje teritorije koje su pripale Kraljevini SHS, Čehoslovačkoj i Rumuniji: „I kao da sve to nije dovoljno, Mađarska se cedi kao sunđer da plati 'odštetu' tim državama Male Antante. Na taj način postoji opasnost da ona ekonomski pođe istim putem kao i Austrija i postane bespomoćni bankrot koji se hrani malom kašičicom". U Ligi su se bojali da će Mađarsku razdjeliti susjedi, kao Francuska Njemačku upadom u Rursku oblast, i na taj način obezbjediti reparacije. ${ }^{4}$

Jugoslavenski poslanik u Londonu je bio mišljenja da se rad Lige ne smije potcjenjivati zbog njenog uticaja na „stvaranje javnog mišljenja u poslovima Centralne Evrope“. U samom Oksfordu Liga je uspjela da pridobije znatan broj studenata za ideju mađarskog integriteta. Ipak, mađarska propaganda nije zahvatila cio Oksfordski univerzitet jer je njen početni uspjeh zaustavljen mobilizacijom antimađarske opozicije - prijatelja Čehoslovačke, Rumunije i Kraljevine SHS (to jest zemalja Male Antante). Zbog sprovođenja „energične propagande“ mađarska vlada je za svoju službu u Londonu angažovala više Engleza pogodnih za propagandu „kako po svojoj spremi tako i po svom socijalnom položaju“. Jugoslavenski poslanik u Londonu je izjavio da u svojoj revnosti Mađari ponekad toliko pretjeruju da „šokiraju“ i same Engleze. Kao najvećeg oponenta mađarskoj propagandi poslanik u Londonu Subotić navodio je Siton Votsona, koji je 1922. dobio vrlo važan položaj profesora istorije na londonskom univerzitetu u Kings Koledžu. On je preko svojih prijatelja i kolega dejstvovao protiv mađarofilske struje i na Oksfordu, gdje je držao predavanja. ${ }^{5}$

U jugoslavenskom Ministarstvu inostranih dela intenzivno su razmišljali o tome na koji način da suzbiju mađarofilsku propagandu u Britaniji. Isticali su da su Srbi u Engleskoj prije rata stekli veliki broj prijatelja, naročito u Oksfordu i Kembridžu, gdje je „u masi smještana“ srpska školska

su objavljeni tekstovi mađarskih saradnika (AJ, fond br. 341, f. 1923/I, Poslanstvo u Londonu - MID-u, političkom odjeljenju, 2. mart 1923).

${ }^{4}$ AJ, fond br. 341, f. 1923/I.

${ }^{5}$ AJ, fond br. 341, f. 1923/f. 2, Poslanstvo u Londonu - MID-u, političkom odjeljenju, 2. mart 1923. 
omladina. I pored povoljnog odnosa Engleza prema Srbiji i srpskim izbjeglicama, ležernost i nezainteresovanost jugoslavenskih vlasti za propagandu u Engleskoj doveli su do toga da su Mađari i Rumuni izbili u prvi plan, osnivajući svoja studentska udruženja i đačke listove. ${ }^{6}$ Nemar jugoslavenskih vlasti ogledao se i u slučaju „neodlikovanih Engleza“ koji su u ratu učinili velike usluge Srbiji. Veliki broj Engleza je znao da je predložen za odlikovanja (agreman štampan u engleskim službenim novinama), ali ordeni nisu stizali da se uruče. ${ }^{7}$

S druge strane, mađarski zvaničnici su uporno širili propagandu o svom prijateljstvu sa Britancima. U govoru održanom u mađarskom parlamentu, predsjednik mađarske vlade grof Betlen je istakao da se „prilikom svog puta u inostranstvo" (Pariz, London, Rim), ${ }^{8}$ nije ni nadao da će imati istorijski uspjeh u namjeri da sa Mađarske skine hipoteku krivice, kojom je bila opterećena u korist Antantinih saveznika. Očekivao je da će dobiti povoljan zajam u slučaju pozitivnog rješenja Reparacione komisije. Betlen se nadao da bi mađarski susjedi imali mnogo više interesa „da nas vide oporavljene ekonomski i finansijski, nego što traže reparacije“, koje Mađari nisu ni mogli platiti, „u našem današnjem tužnom položaju“. Pomoć jedino očekivao „od prijatelja - Engleske i Italije“, koji su Mađarsku i do tada pomagali koliko su mogli. ${ }^{9}$

Mađari su, međutim, i dalje održavali bliske kontakte sa njemačkim militaristima. Ne treba zaboraviti da su bivši njemački „junkeri“ bili na važnim državnim dužnostima u Mađarskoj. Grof Belček, koji je bio u ratu u Francuskoj i Rusiji „kod Hindenburga i Ludendorfa“, postavljen je za poslanika Njemačke u Budimpešti u junu 1923. godine. U vojnom obavještaj-

${ }^{6}$ Isto.

${ }^{7}$ Poslanik je naveo slučaj ambasadora Velike Britanije koji je odlikovan još 1916, ali mu orden nije uručen ni do kraja 1923. godine. U zvaničnoj prepisci Forin ofis se često pitao što je sa brojnim odlikovanjima koja nisu uručena. Poslanik u Londonu Subotić je na kraju samo konstatovao da su sva lica koja su trebala biti odlikovana, „a koja su nas nekad zadužila“, postala indiferentna prema Srbima (Kraljevini SHS), pa čak i „zlo raspoložena“. Za ponovnu mobilizaciju „bivših prijatelja“ protiv mađarske propagande bilo je potrebno okončati dodelu odlikovanja, „o čemu su predlozi davno poslati Ministarstvu inostranih dela" (AJ, fond br. 341, f. 1923/2, Poslanstvo u Londonu - MID-u, političkom odjeljenju, 2. mart 1923).

${ }^{8}$ Jugoslavenski poslanik iz Budimpešte saopštio je da put grofa Betlena u prestonice zapadnih država nije doneo rezultate kojima se nadala mađarska vlada. Reparaciona komisija je postavila teške uslove za dodjelu zajma, uz bitan uslov koji su istakli Jevreji kod zapadnih kapitalista da se zajam može dati Ugarskoj samo „pod uslovom da se ograniči svemoć Gembešove antisemitske bande“, ističe poslanik. (AJ, fond br. 341, f. 1923/f. 2, Jugoslavenski poslanik iz Budimpešte Milojević - ministru Ninčiću, 30. juni 1923).

${ }_{9}$ AJ, fond br. 341, f. 1923/2, Poslanik iz Budimpešte Milojević - MID-u, 7. jun 1923. 
nom odjeljenju Generalštaba Kraljevine SHS zaključili su da je njegovo naimenovanje dokaz da „stari duh junkera vlada u Vilhelmštrase“. Glavni generalštab je iznio interesantan podatak vezan za iznenađujuće militarne aktivnosti „miroljubive“ Švedske koja je mađarskim vlastima dala dozvolu za podizanje vojnih magacina u Švedskoj, „u koje će se smještati oružje i materijal koji budu izradila Nemačka preduzeća u Rusiji“. ${ }^{10}$

S druge strane, predstavnici mađarske emigracije i opozicije, ${ }^{11}$ bivši predsjednik mađarske vlade grof Mihalj Karolji, dr Oskar Jasi, svećenik dr Janoš Hok i Bela Linder, upozoravali su na militaristički karakter mađarske vlasti i države. U svom memoaru od 23. aprila 1923. upoređivali su, na primjer, mirotvorstvo poslijeratne austrijske republikanske države i militarizam mađarske vladajuće elite.

\section{Pitanje austro-mađarskih reparacija}

Treba istaći podatak da je $\mathrm{u}$ britanskom parlamentu u više navrata bila dominantna tema vezana za plaćanje njemačkih, austrijskih, ali i mađarskih reparacija. O toj temi u Domu lordova vođene su diskusije, ali i interpelacije 25. jula 1923. godine. Tako je lord Njutn (Newton) pitao Vladu da li je „ikakav progres učinjen odnosno mađarskih reparacija, jer se to pitanje tiče mira i napretka čitave centralne Evrope“. U obrazloženju tog pitanja lord Njutn je istakao finansijski položaj Mađarske koji je, po njegovom mišljenju, bio očajan. U slučaju zahtjeva da Mađarska plati odštetu, mađarska kruna će izgubiti vrednost, a sama država doživjeti potpuni krah, smatrao je Njutn. Tvrdio je da je jedina nada za tu zemlju da Mađarska dobije zajam preko Društva naroda, a jedina mogućnost da dođe do tog zajma bila je ta da se oslobodi njena izvjesna imovina „koju sada drži Reparaciona komisija kao garanciju za naplatu odštete". Grof Betlen je učinio predlog u tom smislu, koji je bio „simpatično primljen“ od strane britanske i italijanske vlade, ali je bio odbijen od francuske vlade u Reparacionoj komisiji, „presudnim glasom predsednika te komisije, koji je bio Francuz".

\footnotetext{
30. juni 1923.

${ }^{11}$ Mađarski emigranti su vršili propagandu u SAD vezano za osnivanje Demokratsko-republikanske partije i sprovođenje agrarne reforme u Mađarskoj. Na predavanjima po mađarskim kolonijama su govorili i o tome da će „demokratska Mađarska“ uspostaviti dobre odnose sa svojim susjedima, naročito sa Kraljevinom SHS. Karolji se nalazio u Londonu, gdje je uspostavio vrlo dobre veze sa vođom Radničke partije Mek Donaldom, književnicima Bernardom Šoom i Velsom, kao i sa Skotus Viatorom (Siton Votsonom). Karolji se u vreme objave rata nalazio u Americi, gdje je od mađarskog naroda za borbu protiv Austrije i za nezavisnost Mađarske prikupio 18.000 dolara, koji su se nalazili u američkim bankama. (AJ, fond br. 341, f. 1924/I, Generalni konzul Kraljevine SHS - Kraljevskom poslanstvu u Londonu, 24. januar 1924)
}

${ }^{10}$ AJ, fond br. 341, f. 1923/f. 2, Glavni Đeneralštab, obaveštajno odeljenje - MID-u, 
Po Njutnu, Mađarska je bila osuđena na ekonomsku propast, „ako ne i na nešto gore“. On se čudio što Mađarska uopšte ima da plaća odštetu, „kada je ona u Parizu bila strože tretirana no ijedna druga neprijateljska država": „Od svršetka rata Mađarska je učinila velike žrtve, izvršivši velike isplate u naturi Italiji, Srbiji, Rumuniji i Grčkoj“. Njutn je više optuživao predstavnike Male Antante koji su „često dolazili u Englesku za novac“, pa je zato predlagao da se vladama tih država ne da ni peni dok ne pristanu na „pravedno i zadovoljavajuće rješenje mađarskih reparacija“. Interpelaciju je završio s „kulturološkom nevinošću“ Mađarske: „Užasno je to da ijedna kulturna država bude osuđena na ekonomsku propast, samo da bi se zadovoljila politička mržnja“. ${ }^{12}$

Njutna je u diskusiji podržao lord Karnvud (Charnwood), rekavši da Njutn nije pretjerao u iznošenju nedaća koje je Mađarska pretrpjela od mirovnog ugovora. Lord Parmor (Parmoor) je potom upitao da li bi lord Kurzon (Curzon) mogao upotrebiti uticaj Velike Britanije da za Mađarsku isposluje iste privilegije zajmova koje su date Austriji. Lord Lamington je istakao da je za malu zemlju nemoguće da pokaže bilo kakav trgovinski napredak ako su njeni susedi udruženi da je spreče u vođenju ma kakve spoljne trgovine. Budući da su carinske tarife uperene protiv Mađarske, Lamington je smatrao da toj zemlji treba dati „izvjestan odmor" kakav je dat Austriji.

Odgovarajući na pitanje Njutna, lord Kurzon nije bio previše milosrdan prema mađarskoj ekonomskoj situaciji, rekavši da je Mađarska, zajedno sa Austrijom, prema članu 161 Trijanonskog mirovnog ugovora primila na sebe „punu odgovornost za štetu“ koju je Austro-Ugarska imperija nanijela savezničkim silama za vreme rata, i da je određena provjerena Reparaciona komisija da procjeni nastalu štetu.

Protiv zajedničkog predloga Britanije i Italije (u prilog opraštanja dela reparacija Mađarskoj i Austriji) bio je francuski predstavnik i delegat koji su zajednički predstavljali države Male Antante, Grčku i Poljsku, te je taj predlog na kraju oboren presudnim glasom francuskog predsednika Reparacione komisije. Lord Kurzon je komentarisao da je za žaljenje što francuska vlada nije diskutovala situaciju s britanskom vladom prije nego je preduzela takav korak. Britanska vlada je pružila punu pomoć mađarskom apelu silama koje su bile zastupljene u Reparacionoj komisiji, te je uputila i specijalan apel na Francusku, istakao je Kurzon. „Vlada je željna da predupredi finansijski pad Mađarske sa svima posljedicama koje bi taj pad izazvao. Ona želi da vidi u dejstvu, što prije, potpun plan za rekonstrukciju, sa pogodnim garancijama, jer ona zna iz primjera Austrije, da odugovlačenje

${ }^{12}$ Isto, „Mađarske reparacije. Interpelacije i diskusija u Domu Lordova 25. jula 
izaziva gubitak većih suma novca... Vlada je zatim uvjerena da se nikakva finansijska pomoć ne može dati u dovoljnoj mjeri, ako Liga Naroda ne pomogne takav plan. Britanska vlada sumnja da bi ikakav plan za balansiranje mađarskog budžeta mogao zadobiti povjerenje finansijskog svijeta, ako taj plan ne bude iznesen sa autoritetom Finansijskog odbora Lige naroda", ocijenio je držanje britanske vlade prema mađarskom problemu.

Engleska štampa nije komentarisala diskusiju o mađarskim reparacijama, koju je svojom interpelacijom izazvao lord Njutn, stoga što joj je bila poznata mađarofilska propaganda koju je lord Njutn vodio u Engleskoj. On je koristio svaku pogodnu priliku da skrene pažnju javnosti na Mađare i na njihov položaj. Mađarska je svirepije kažnjena ugovorom o miru, iako je, prema Njutnu, „uvijek pokazivala velike simpatije za Englesku“. Nekoliko članova Gornjeg doma zagovaralo je sličnu ideju, ali je opšte mišljenje engleskih krugova i Vlade o Mađarskoj uglavnom bilo izraženo navedenim govorima lord Kurzona i Greja, tj. vladinog predstavnika i vođe opozicije u Gornjem domu.

Mađarsku su u šaci držale zemlje Male Antante, pošto je njen jedini spas ležao u aranžmanu koji je i Austriji pomogao da izađe iz „očajnog stanja“, ali se takav aranžman nije mogao postići bez pristanka Male Antante. Ipak je s vremenom Mala Antanta pokazivala sklonost da „oslobodi mađarske zaloge", koji su se držali kao garancija za plaćanje reparacija, a koji su mogli poslužiti kao podloga za međunarodni zajam Mađarskoj. Pojedini engleski listovi, međutim, upozoravali su na mogućnost da Mađarska upotrebi zajam za svoje vojničko jačanje radi stvaranja nereda. ${ }^{13}$ Engleska javnost je željela da Mađarska pođe austrijskim „republikanskim mirnim putem", kako bi joj se mogle dati olakšice.

Mađarska se, međutim, nije odricala starih iredentističkih težnji, zalažući se za revizionizam (revizija mirovnih ugovora) i poraženi habzburški legitimizam. U tom pravcu je išlo „izmirenje“ regenta Hortija sa Habzburgovcima u proljeće 1924. godine. Tako je nadvojvoda Jozef Habzburški više od mjesec dana (februara i marta 1924) prisustvovao svim sjednicama Višeg ratnog savjeta Mađarske u svojstvu „vrhovnog komandanta i načelnika Glavnog generalštaba mađarske vojske“. Prava Otonova kao punopravnog Karlovog nasljednika, na habzburškom prestolu, svečano su priznata od Mađara. Horti je pristao da preda vlast Otonu, izražavajući nadu da će predati Vladu legitimnom suverenu, i to „cele i osvećene“ Mađarske. Ovaj čin je predstavljao „prosto i čisto“ izmirenje Hortija sa Habzburgovcima. ${ }^{14}$

${ }^{13}$ Tajms, 31. jul 1923.

${ }^{14} \mathrm{U}$ istom dopisu se navodi da je mađarski poslanik u Sofiji Kiš de Nemesker potpisao u Angori početkom januara 1924. „Ugovor prijateljstva“ sa Turskom. Prethodno su se mađarske vojne ličnosti sastajale sa turskim vojnim zvaničnicima u Sofiji. Radilo se na tome 
Mađarska revizionistička akcija je jačala tokom 1924. godine, naročito sa velikohrvatskim revizionistima koji su radili na poništenju „versajske tvorevine" - Kraljevine Srba, Hrvata i Slovenaca. Mađarski legitimisti su se povezivali sa Stjepanom Radićem, koji je u više navrata obišao mađarsko poslanstvo u Beču. Stupio je u vezu sa mađarskim legitimistima. Primio je u posjetu saradnika mađarskog legitimističkog lista Mađarorsag i sa njime razgovarao o mogućnosti konfederacije hrvatsko-mađarske-slovenačke. Mađari su vršili stalnu propagandu u inostranstvu. Početkom 1924. u Londonu je objavljena knjiga grofa Telekija o mađarskoj revoluciji. ${ }^{15}$

\section{Mađarski dokumenti o odgovornosti Beča i Berlina za rat}

I pored svih nastojanja, Mađari se nisu mogli izvući od odgovornosti za rat i ratna razaranja. Oni su, s druge strane, smanjivali svoju ulogu u ratnoj austro-njemačkoj koaliciji, pa su vršili propagandu u pravcu umanjenja krivice za rat. U tu svrhu su tokom 1924-26. publikovali dokumentaciju vezanu za odgovornosti Beča i Berlina za rat. Otežavajuća okolnost koja je prikazivala Njemačku kao jednog od glavnih izazivača Velikog rata, proizlazila je tako iz dokumentacije saveznice Centralnih sila - Mađarske. Naročito su bili optužujući dokumenti iz korespondencije predsjednika mađarske vlade grofa Tise, a posebno „jedan dokument grofa Tise po kome su Austrija i Njemačka provocirale evropski rat". U tom dokumentu se iznosi stav da je čak i bečka štampa demaskirala u punoj svetlosti krivce evropskog rata. Naime, u korespondenciji grofa Tise, koju je 1924. objavila Mađarska akademija nauka, u jednom Tisinom pismu caru Francu Jozefu otvoreno se navodi da je Austrija 1914. godine provocirala rat sa Srbijom.

U pismu grofa Tise njemačkom ambasadoru u Beču, Čirškom, od 5. novembra 1914. godine, ističe se i slijedeće: „Pre svega treba naglasiti da smo se mi, pre početka naše srpske akcije, posavetovali sa Nemačkom i da smo na direktno podsticanje (sokoljenje ili hrabrenje) njemačke vlade i na njenu izjavu, da ona sadašnju situaciju smatra kao povoljnu za sve više preteći obračun, preduzeli demarš u Beogradu." Autor je zaključio da se iz ovog pisma jasno vidi da su Austrija i Njemačka provocirale svjetski rat i da je potrebno da malo prokomentariše "ove Tisine redove" kako bi se bolje shvatio njihov značaj: „Mnogobrojnim dokumentima dosad je utvrđeno da

\footnotetext{
da se stvori vojna konvencija koja bi imala „glavni zadatak da zavadi Kemal pašinu Tursku sa Venizelosovom Grčkom, a ovaj sukob bi imao biti znak za akciju Bugara u Makedoniji, što bi prinudilo Kraljevinu SHS da se mobiliše“. Taj projekt, koji je pripremio bivši kralj Ferdinand Koburški, predviđa saradnju Turaka, Bugara, Bavaraca, pa čak i Italije (AJ, fond br. 341, f. 1924/f. 1, MID, Političko odjeljenje - Kraljevskom poslanstvu u Londonu, 20. mart 1924).

${ }^{15}$ Isto.
} 
su Nemačka i Austro-Ugarska 'htjele' obračun najdalje do jeseni 1914. godine. Po njihovom računanju taj bi rat, ako bi se $u$ tome roku poveo, za njih bio pobedonosan, što ne bi, po istom računu, moralo biti ako bi se ugazilo u rat godinu ili dve docnije. Naročito je Balplac (austrijski MIP - N. Ž) insistirao na tome da se što pre ulazi u 'obračun'. To njegovo ratničko izazivačko raspoloženje specijalno je manifestovano 1913. i 1914. godine. Razne mahinacije i provokacije iz toga doba, kao i ceo štimung bečke štampe posle balkanskih ratova do ultimatuma Srbiji, isuviše su dobro poznati a da bi ih ponovo trebalo ponavljati“. ${ }^{16}$

Grof Tisa je bio jedan od rijetkih i usamljenih austro-mađarskih funkcionera koji se taktički, u pogledu pitanja kad treba ući u rat, razilazio sa vladajućim krugovima u Beču i Berlinu. Tisa je smatrao da je bilo rano za rat $\mathrm{u}$ to doba, posebno zato što je na Balkanu i u Evropi „momentalno nepovoljna konstelacija“ za obračun, koji je „imao i morao doći godinu dana ranije ili kasnije“. I kada je drugi dan poslije Sarajevskog atentata grof Berthold saopštio Tisi „da će se gaziti u rat" protiv Srbije, Tisa je požurio i napisao bečkom caru "ono pismo" u kome mu obraća pažnju na nepovoljnost situacije za ulaženje $u$ rat. „Provokatorstvo je na pitanju atentata $u$ Sarajevu ratovati, naročito s obzirom na fakat da ničim nije utvrđeno da je Srbija imala učešće u tom činu“, ističe Tisa. Ipak je bečki „Balplac“ bio mnogo jači od Tise, dok je sam Franc Jozef ignorisao savjete i opomene svog mađarskog predsjednika vlade. Poslije nekoliko dana i Tisa je bio prinuđen da usvoji Bertholdovu ratnohuškačku tezu.

U dokumentima se iznosi jedan važan detalj, nepoznat jugoslavenskoj javnosti do sredine dvadesetih godina, koji je prethodio Tisinom preokretu i upozorenju upućenom bečkom „Balplacu“. Naime, Tisa bi bio za „gaženje u rat" 1914. ako bi se uvjerio da su faktori u Berlinu procijenili da je nastupio povoljan trenutak za obračun sa Srbijom, „koji se sve više nametao", kako je i po Tisinom razgovoru sa Čirskim, izjavila njemačka vlada. U dobro obaviještenim krugovima tvrdilo se da je istom prilikom Tisa tražio od Berlina izvjesne garancije za Mađarsku, koje je dobio od samog cara Viljema, „koji nije sumnjao u pobjedu“.

Ne treba, ipak, zaboraviti istorijsku činjenicu da je Tisa prvenstveno bio nacionalni Mađar, mnogo više nego što je bio austrougarski državnik, pa je preko izjava o "nepovoljnoj vojnoj i političkoj konstelaciji“ izražavao bojazan za sudbinu svoje domovine Mađarske poslije ulaska u obračun sa Srbijom. Izraženo "mađarstvo" Tisa je isticao u pismu Čirskom, u kome je na više mjesta izražavao mađarski nacionalizam. Po Tisinim zapisima, taj nacionalizam je bio usko vezan za sudbinu Austro-Ugarske i „njemačkog saveznika“. Zbog mađarskih bojazni da bi sa propašću austro-njemačke

\footnotetext{
${ }^{16}$ AJ, fond 335, f. 1, Dokumenti iz korespondencije grofa Tise, n. n.
} 
vojne akcije propala i mađarska kraljevina, njemačka vlada je bila odlučna „da se zagazi u rat" protiv Srbije upravo u trenutku Sarajevskog atentata. Predosjećajući budući poraz, za Tisu je bilo sudbonosno pitanje mađarskog opstanka ulaskom u rat sa Srbijom odmah poslije atentata u Sarajevu.

Pojedini bečki listovi sredinom dvadesetih godina komentarisali su Tisinu korespondenciju. Wiener Allgemeine Zeitung je objavio Tisinu korespondenciju pod naslovom „Tisa Čirskom o krivici Rata“. List Der Abend reprodukovao je isto pismo pod naslovom „Tisa o Svjetskom ratu - dokazi od istorijske važnosti“. U podnaslovu „Ratna krivica“, prije pasusa iz pisma ranije navedenog, Der Abend je dao slijedeći komentar: „Pismu koje je Tisa uputio Čirškom, poslaniku njemačkog carstva u Beču, treba da obrati pažnju svaki istinski prijatelj mira. Zna se koliko se amo i tamo pisalo o krivici rata i kako se naročito u nacionalističkim krugovima nije prestajalo naglašavati da smo mi vodili jedan sveti, od Boga nametnuti odbrambeni rat (istaknuto u originalu - N. Ž). Petog novembra, dakle, jedva tri meseca posle provale rata, u doba kad su uspomene bile još sveže, piše Tisa... (Sad dolazi citat koji smo i mi prethodno naveli, pr. prev.)". Poslije citata Der Abend je naveo da je sve ovo „nepobitan dokumenat“ i da zaslužuje najveću pažnju zbog svoga svetsko-istorijskoga značaja. Pod pojmom „nepobitan dokumenat" Der Abend je mislio na utvrđivanje ratne krivice. U članku je na kraju konstatovano: „I za nas je to jasno“. ${ }^{17}$

Njemačka i austrijska štampa sredinom dvadesetih godina nisu prestajale da agresivnim člancima bombarduju evropsku javnost o isključivo srpskoj krivici za Veliki rat. Berliner Tagblat od 18. marta 1925. godine, u članku „Pitanje krivice za rat" iznosi polemiku Alfreda Vegerera, šefa „Centralnog mesta za ispitivanje ratnih uzroka“, sa prof. Nikolom Murej Betlerom, koji je u januarskoj svesci mjesečnog časopisa Di Krigsšuldfrage okrivio Njemačku kao odgovornu za svjetski rat. Vegerer je profesoru Betleru „preporučivao“ da, „za slučaj da se još jednom odluči da u svojoj naučničkoj sobi prostudira pitanje o krivici za rat", nauči da pravi razliku između austrijsko-srpskog konflikta i svjetskog rata.

Pored mađarske, i u dijelu njemačke publicistike i štampe bilo je, dakle, napisa u kojima su se objektivno iznosile primjedbe na austrijske predratne dokumente. Tako je u liberalnom Berliner tageblatu od 1. aprila 1930. objavljen članak Herberta fon Hindenburga u kojem su iznesene kritike na račun ponašanja njemačkog političkog vodstva u odnosu na austrougarsku politiku. Fon Hindenburg je analizirao pitanje ratne odgovornosti Austro-Ugarske i Njemačke i s njim povezanog pitanja plaćanja ratnih reparacija. Austrija se, po njemu, preko svog „novog prijatelja“ Italije uspjela u

${ }^{17}$ Isto. 
dobroj mjeri osloboditi reparacija, ali je ostala njemačka krivica u okviru odgovornosti za svjetski rat. Evropa „može doći do mišljenja“ da je samo onaj ko plaća reparacije „jedini krivac za svjetsko krvoproliće“, zaključuje Hindenburg. Njemačka krivica je po njegovom mišljenju u drugom planu odgovornosti za izbijanje svjetskog rata, a na prvom mjestu je krivica Austro-Ugarske monarhije. U ovom članku se, dakle, prikazuje tobožnja njemačka ratna naivnost $\mathrm{u}$ odnosu na Austriju, dakle naivno prebacivanje odgovornosti unutar saveznica - Centralnih sila. ${ }^{18}$

Ne treba zaboraviti činjenicu da je u Austriji i Njemačkoj bilo pojedinaca i iz naučnih krugova koji su objektivno pisali o sarajevskom događaju i uzrocima izbijanja rata. Jedan od takvih bio je ugledni istoričar i publicista dr Herman Vendel. Svoj članak, objavljen u Arbajter Cajtungu 26. jula 1927, posvetio je „austrijskoj dinastičkoj osionosti i egoizmu i njemačkom političkom šarlatanstvu" kod pitanja optužbe za rat.

Vendel na kraju donosi slijedeći zaključak o krivici austrijskih militanata: „Ako je čuvanje austrougarskog prestiža velike sile čisto ludilo moći dakle, za Konrada bilo dovoljan razlog ratu, kod habzburških vlasti vladalo je mišljenje da se Dunavska monarhija, u čijoj je utrobi jugoslovensko pitanje svakog dana sve opasnije vrilo, može spasti samo ogromnom banjom krvi. Ali što oni nisu mogli na drugi način savladati ovaj problem, njihova je vlastita krivica. Bezutešna situacija služi im kao olakšavajuća okolnost samo toliko koliko jednom poslovnom čoveku koji svojom vlastitom krivicom, postavši nesposoban za plaćanje, potpali svoju kuću da bi izbegao bankrotiranje i tako zapali celu ulicu“. ${ }^{19}$

Na kraju treba istaći da je u nadmudrivanju između bivših austronjemačkih saveznika: ko je veći krivac za rat? - Mađarska dospela u drugi plan jer je u eter proturala dokumentaciju koja ju je u dobroj mjeri abolirala od odgovornosti za izazivanje Velikog rata.

${ }^{18}$ H. fon Hindenburg, „Jedna primjedba na austrijske predratne dokumente“, Berliner tageblat, 1. april 1930.

${ }^{19}$ AJ, fond 335, f. 1. 
Nikola Žutić

\title{
HUNGARIANS ON THEIR RESPONSIBILITY \\ FOR THE GREAT WAR 1919-1929
}

\begin{abstract}
Summary
The article analyzes the relationship of the Great Britain towards Hungary, Germany and Austria. It also analyzes the articles from the press of the mentioned countries that were present in the European public stressing the Entante and the Serbian "guilt" for the Great War. On the other hand, this article stress the individuals in the scientific community of the defeated countries, especially those, who are objectively wrote about Sarajevo 1914 events and the causes of the outbreak of Great War. For example, an eminent German historian and publicist Herman Wendel and some examples of the Hungarian press who supported the „Versailles assertion" that Berlin pushed its allies into the War. Furthermore, the article highlights the Hungarian sources which showed that Germany was one of the main drivers of the Great War. In particular, the documents from the correspondence of the Count Tisza who was President of the Hungarian government. The conclusion was that Count Tisza was a rare and isolated Austro-Hungarian political official, who estimated that was too early for war. Tisza regarded that in the Balkans and in Europe is „currently unfavorable constellation" for an payoff, which would "have to come one day sooner or later."
\end{abstract}

